\title{
PEMBERITAHUAN KETERLAMBATAN ANGSURAN MENGGUNAKAN SHORT MESSAGE SERVICE GATEWAY (STUDI KASUS KOPERASI SIMPAN PINJAM MAKMUR YOGYAKARTA)
}

\author{
Jalu Satrio Wibowo(1), Herry Sofyan(2), Bambang Yuwono(3) \\ Jurusan Teknik Informatika Fakultas Teknik Industri UPN “Veteran” Yogyakarta \\ Jl. Babarsari 2 Tambakbayan Yogyakarta \\ e-mail : jalusatrio23@gmail.com ${ }^{(1)}$, herrysofyan@gmail.com ${ }^{(2)}$, bambangy@upnyk.ac.id(3)
}

\begin{abstract}
In this globalization era, the development of information technology has undergone rapid changes. This can be seen by the number of companies or business entities or agencies that cannot be separated from the influence of information technology. One of them is Koperasi Simpan Pinjam Makmur Yogyakarta Savings and Loan Cooperative as a social economic business entity which is a joint effort based on the principle of family. Every form of activity and business in general has a obvious purpose so that in managing cooperative activities, officers must provide believes and provide good services for the members. Some problems in carrying out cooperative activities include delinquency due to late installment payments, lack of efficient employee performance, delays in notification that makes obstructed payment installments, and lack of data recording by bookkeeping and then it less computerized in recording cooperative data if done by the usual way of checking data one by one it requires a considerable amount of time in searching for member data that has problems with missing data in searching for cooperative data files not including those that are not found causing less recorded data so that it is still less efficient and not to mention the problem less notice is conveyed so that there are still members who are in arrears in installment payments each month causing the cooperative to work more especially notifying payments by texting one by one each member who is waiting with officers who are still less involved in inefficiencies
\end{abstract}

Keywords : Koperasi, SMS Gateway, Web, PHP, Javasript, SMS, Waterfall

\begin{abstract}
Abstrak
Perkembangan teknologi informasi di era globalisasi ini telah mengalami perubahan yang cukup pesat. Hal ini dapat lihat dengan banyaknya perusahaan atau badan usaha atau instansi tidak lepas dari pengaruh teknologi informasi. Salah satunya adalah Koperasi simpan pinjam Makmur Yogyakarta sebagai badan usaha ekonomi rakyat yang bersifat sosial yang merupakan usaha bersama berdasarkan atas azas kekeluargaan. Setiap bentuk kegiatan dan usaha pada umumnya memiliki sebuah tujuan yang jelas sehingga dalam mengelola kegiatan koperasi oleh petugas harus memberikan kepercayaan dan memberikan pelayanan yang baik bagi anggotaanggota koperasi. Permasalahan dalam menjalankan kegiatan koperasi antara lain penunggakan dikarenakan keterlambatan pembayaran angsuran, kinerja petugas yang kurang optimal, keterlambatan dalam pemberitahuan informasi yang membuat pembayaran angsuran terhambat, dan pencatatan data dengan pembukuan lalu di memasukan data ke dalam Microsoft excel sehingga kurang terkomputerisasi dalam merekam data koperasi maka apabila dilakukan dengan cara seperti biasa mengecek data satu persatu maka memerlukan waktu yang cukup lama dalam mencari data anggota yang memiliki permasalahan data hilang dalam mencari file data koperasi belum termasuk juga yang tidak ditemukan menyebabkan data kurang terekam dengan baik sehingga masih kurang efisien dan belum lagi masalah pemberitahuan yang kurang tersampaikan sehingga masih ada anggota yang menunggak pembayaran angsuran pada setiap bulannya menyebabkan pihak koperasi bekerja lebih terutama memberitahu perihal pembayaran dengan sms satu persatu kesetiap anggota yang menunggak dengan petugas yang masih kurang turut menjadi masalah kurang efisen.
\end{abstract}

Kata Kunci : Koperasi, SMS Gateway, Web, PHP, Javasript, SMS, Waterfall 


\section{PENDAHULUAN}

Di era globalisasi seperti sekarang, perkembangan teknologi telah mengalami banyak perubahan yang cukup signifikan sehingga dapat mempengaruhi seluruh aspek kehidupan manusia. Perubahan-perubahan ini dapat dilihat sebagai contoh yaitu banyaknya badan usaha atau instansi yang tidak lepas dari pengaruh teknologi. Dengan banyaknya instansi yang memanfaatkan teknologi informasi, suatu instansi dapat menjalankan pekerjaannya secara efektif dan efisien (Kompasiana, 2014). Salah satunya adalah Koperasi simpan pinjam Makmur Yogyakarta sebagai badan usaha ekonomi rakyat yang bersifat sosial yang merupakan usaha bersama berdasarkan atas azas kekeluargaan. Setiap bentuk kegiatan dan usaha pada umumnya memiliki sebuah tujuan yang jelas sehingga dalam mengelola kegiatan koperasi oleh petugas harus memberikan kepercayaan dan memberikan pelayanan yang baik bagi anggotaanggota koperasi (Nindyo P.1986: 9).

Kegiatan dalam operasional koperasi memiliki banyak permasalahan tidak terkecuali koperasi makmur. Beberapa permasalahan dalam menjalankan kegiatan koperasi antara lain penunggakan dikarenakan keterlambatan pembayaran angsuran, kinerja petugas yang kurang optimal, keterlambatan dalam pemberitahuan informasi yang membuat pembayaran angsuran terhambat, dan pencatatan data dengan pembukuan lalu di memasukan data ke dalam Microsoft excel sehingga kurang terkomputerisasi dalam merekam data koperasi maka apabila dilakukan dengan cara seperti biasa mengecek data satu persatu maka memerlukan waktu yang cukup lama dalam mencari data anggota yang memiliki permasalahan data hilang dalam mencari file data koperasi belum termasuk juga yang tidak ditemukan menyebabkan data kurang terekam dengan baik sehingga masih kurang efisien dan belum lagi masalah pemberitahuan yang kurang tersampaikan sehingga masih ada anggota yang menunggak pembayaran angsuran pada setiap bulannya menyebabkan pihak koperasi bekerja lebih terutama memberitahu perihal pembayaran dengan sms satu persatu kesetiap anggota yang menunggak dengan petugas yang masih kurang turut menjadi masalah kurang efisen.

Sedangkan teknologi untuk pemberitahuan informasi perihal pembayaran angsuran yang ada, memiliki beberapa sisi kekurangan dan kelebihan. Tapi dengan kemajuan teknologi terdapat teknologi yang saat ini dapat membantu menjawab permasalahan mengenai pemberitahuan angsuran untuk koperasi, yaitu dengan memanfaatkan teknologi SMS Gateway memanfaatkan gammu sebagai penyedia sarana SMS. Contoh penelitian yang pernah dilakukan oleh Kharismawan Pudyastowo yaitu mengenai donor darah menggunakan SMS Gateway. dikarenakan sistem yang masih manual khususnya di Unit Donor Darah dalam menginformasikan persediaan darah dikarenakan banyaknya data yang harus diolah dibutuhkan ketelitian dan publikasi kepada publik dengan memanfaatkan internet dan SMS Gateway dengan jaringan Global System for Mobile Communication (GSM), maka masyarakat dan intansi dapat melihat informasi tentang stok darah melalui website dalam pengunaannya dengan memanfaatkan gammu yang mengambil data no.telpon yang dimiliki setiap anggota untuk pengelolaan SMS (Kharismawan P, 2014).

Maka permasalahan mengenai penunggakan angsuran dan pengelolan data merupakan alasan utama dalam membangun sebuah aplikasi dengan teknologi SMS Gateway memanfaatkan gammu. Aplikasi pemberitahuan keterlambatan menggunakan SMS Gateway diharapkan membantu koperasi dalam pemberitahuan angsuran dan pengelolaan data koperasi dan bagi anggota dapat menerima pemberitahuan informasi perihal angsuran. Selain itu dengan adanya aplikasi ini diharapkan dapat meningkatkan kualitas pelayanan sehingga diharapkan dapat membantu memudahkan koperasi dalam proses pengelolaan data dan pemberitahuan pembayaran angsuran kepada setiap anggota koperasi dan membuat waktu lebih efisien untuk kelancaran kegiatan koperasi diharapkan dapat mencapai tujuan koperasi. 


\section{METODOLOGI PENELITIAN}

Dalam bab ini akan dijelaskan tentang metodologi penelitian dan pengembangan sistem dalam pembuatan aplikasi ini menggunakan metode pengembangan sistem yang digunakan pada penelitian ini adalah metode waterfall yang dikembangkan oleh (Pressman, 2010). Pada penelitian ini metode waterfall digunakan sampai penulisan koding dilanjutkan pengujian. Tahapan awal pembuatan penelitian dilakukan dengan adanya analisis dari permasalahan. Analisis dilakukan dengan melakukan studi pustaka dan observasi pencarian data. Dengan adanya hasil pada tahapan sebelumnya maka muncul latar belakang dari permasalahan yang ada. Tahapan selanjutnya adalah membuat analisis kebutuhan dari sistem yang dibuat. Pada penelitian ini yang dilakukan hanya sampai pada tahap pengujian

Metode Rekayasa Perangkat Lunak WATERFALL

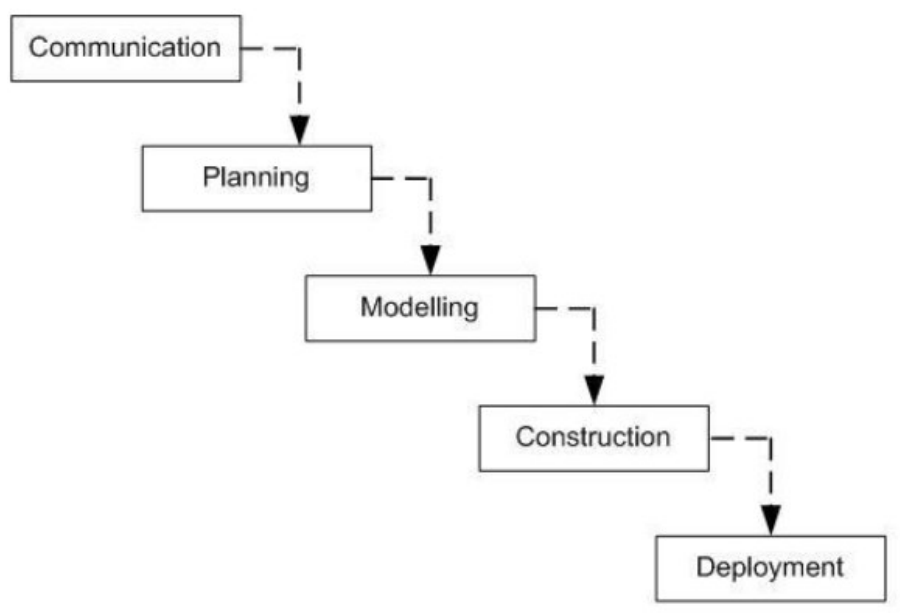

Gambar 1. Alur Penelitian Waterfall Menurut (Presman 2010)

Metode waterfall memiliki beberapa tahapan yang terstruktur dan berurutan. Proses awal atau tahapan awal yaitu proses pengumpulan informasi dengan observasi dan studi pustaka yang nantinya dijadikan sebagai latar belakang permasalahan. Penelitian dilanjutkan dengan tahapan planning pada tahapan ini peneliti melakukan perencanaan mengenai bagaimana tahapan proses penyelesaian masalah dan hasil dari planning dituangkan dalam tahapan modelling. Kemudian tahapan terakhir adalah dengan pengkodean.

Proses penyelesaian hasil penelitian dilakukan dengan menggunakan tiga tahapan. Tahapan communication awal dilakukan dengan melakukan studi pustaka dan analisis data terhadap permasalahan yang dibahas dalam penelitian, kemudian memberikan pandangan yang lebih detail selanjutnya melakukan tahap observasi ke lapangan untuk mendapatkan data. Proses pengumpulan informasi mengenai permasalahan yang diangkat juga dilakukan dengan tahapan wawancara dengan narasumber yang berkaitan dengan permasalahan. Kemudian melakukan tahapan selanjutnya yaitu melakukan perencanaan lanjutan untuk menyelesaikan permasalahan dalam penelitian. Kemudian tahap analisis kebutuhan software dan modeling \& planning merupakan proses perencangan software sebelum ke proses pengkodean atau tahap terakhir construction . 


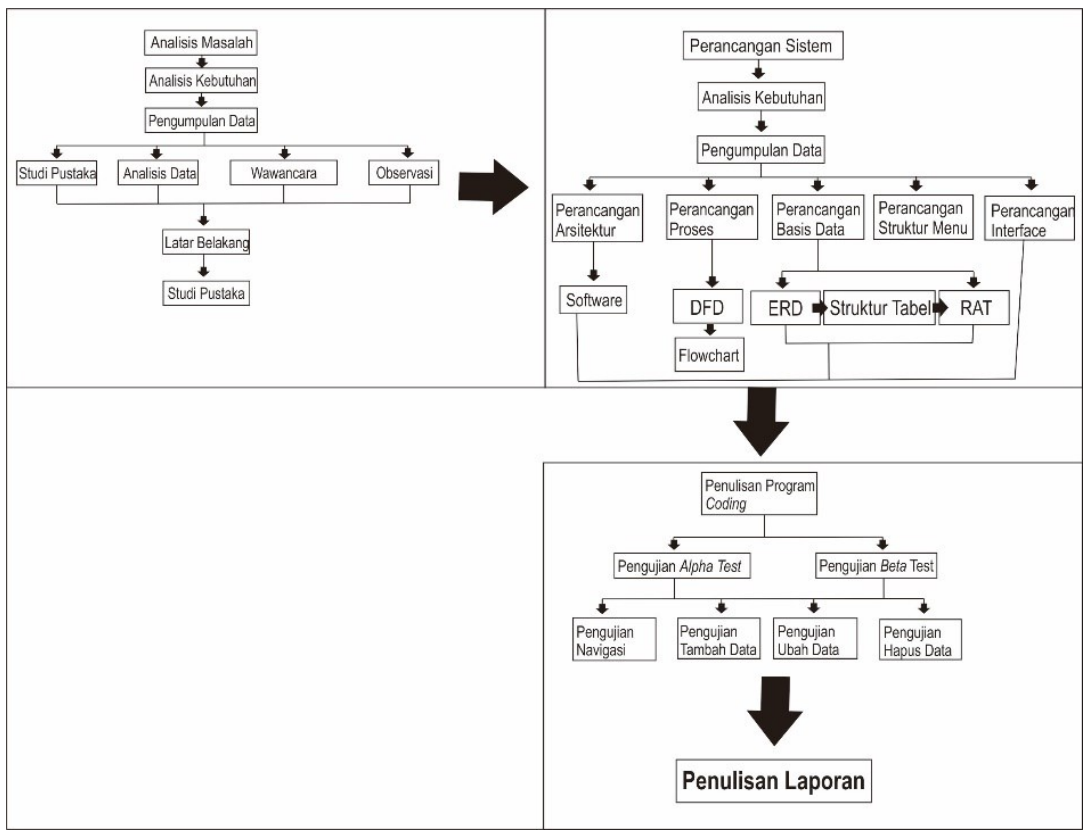

Gambar 2. Skema tahapan penelitian

\subsection{Obyek Penelitian}

Objek yang diteliti dalam penelitian ini adalah bagaimana alur simpanan pinjaman dan pembayaran angsuran pada sistem KSP Makmur Yogyakarta yang berlokasi di Jl. Cantel Baru.

\subsection{Metode Pengumpulan Data}

a. Studi Pustaka

Merupakan metode pengumpulan data dengan cara mengumpulkan data-data dari perpustakaan atau perpustakaan online yang mendukung penelitian baik itu dari buku mengenai, jurnal ilmiah, maupun artikel yang membahas dan mendukung penelitian ini. Dengan mempelajari literature yang sesuai dengan proses penelitian yang dilakukan.

b. Observasi

Merupakan metode pengumpulan data dengan melalui observasi dengan pengamatan secara langsung pada KSP Makmur Yogyakarta untuk memperoleh data dari pihak KSP Makmur Yogyakarta mengenai sistem simpan pinjam dan pembayarn angsuran dalam koperasi. Pada tanggal 30 april - 5 mei 2018 dengan menggamati proses kegiatan koperasi khususnya simpan pinjam angsur secara langsung.

c. Wawancara

Wawancara merupakan salah satu langkah yang dilakukan sebagai teknik pengumpulan data dengan cara bertatap muka secara langsung untuk memperoleh informasi. Metode ini digunakan untuk Tugas Akhir dengan mewawancarai ketua koperasi, petugas dan anggota Koperasi Makmur Yogyakarta sejumlah 6 orang.

\subsection{Tinjauan Literatur}

Pada tahap ini, penulis berdasarkan data yang didapat dari pihak KSP Makmur yang masih menggunkan metode layanan yang sekarang dengan semi manual / manual ini lebih menitik beratkan kepada petugas dari pihak koperasi baik untuk bisa mengatasi permasalahan secara manual didalam koperasi. Sistem ini memiliki banyak kekurangan dan kurang efektif, akan tetapi masih digunakan oleh pihak koperasi.

\section{Metode Rekam Data Manual}

Metode data yang di gunakan pihak koperasi dinilai kurang efisein dalam penyimpanan data memungkinkan terjadi data yang hilang hasil data yang dimasukan kedalam data excel 
sebelumnya sehingga dapat berakibat kurang amannya data dan keterlambatan pembayaran angsuran menjadi sebuah permasalahan tersendiri ketika pengelolaan koperasi menggunakan memasukan data yang telah dibukukan ke excel saat data ingin tinjau kembali masih ada beberapa data yang belum terekam secara baik sehingga membutuhkan waktu.

\section{Metode Pemberitahuan Informasi Manual}

Dengan metode SMS satu persatu kepada setiap anggota yang membutuh waktu yang cukup lama . Cara kerja dengan metode ini, dengan SMS satu persatu dan dalam beberapa penyampaian informasi masih belum dapat tersampaikan kepada setiap anggota koperasi hingga penunggakan dan keterlambatan pembayaran angsuran dapat terjadi . untuk petugas membutuhkan tenaga hingga konsentrasi yang cukup dengan petugas koperasi yang jumlahnya masih kurang.

Tabel 1. Perbandingan Sistem

\begin{tabular}{|c|c|c|}
\hline Perbandingan & $\begin{array}{c}\text { Aplikasi Pemberitahuan } \\
\text { Keterlambatan Angsuran } \\
\text { Menggunakan Short } \\
\text { Message Service Gateway } \\
\text { (Studi Kasus Koperasi } \\
\text { Simpan Pinjam Makmur } \\
\text { Yogyakarta) }\end{array}$ & $\begin{array}{c}\text { Sistem Koperasi Simpan } \\
\text { Pinjam Makmur Yogyakarta } \\
\text { Sekarang }\end{array}$ \\
\hline Rekam Data & Telah terorganisir berbasis Web & Manual melalui excel \\
\hline Pemberitahuan & Memanfaatkan SMS Gateway & Manual satu-satu menggunakan surat atau SMS \\
\hline Hasil & 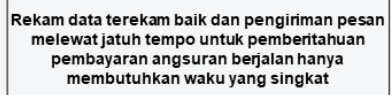 & $\begin{array}{l}\text { Rekam data masin mengandalkan memasukan data } \\
\text { dalam excel dan pengiiriman SMS manual } \\
\text { membutuhkan waktu yang lama }\end{array}$ \\
\hline
\end{tabular}

\section{SMS Gateway}

Menurut (Sunardi, 2009)," SMS Gateway adalah teknologi mengirim, menerima dan bahkan mengolah SMS melalui komputer dalam sistem komputerisasi biasanya digunakan pada aplikasi bisnis baik kepentingan promosi, penyebaran informasi pada pengguna".Seperti kita ketahui, pada jaman sekarang, hampir semua individu telah memiliki telepon selular (handphone), bahkan ada individu yang memiliki lebih dari satu handphone.SMS merupakan salah satu fitur pada handphoneyang pasti Skema dapat di lihat pada Gambar 3.

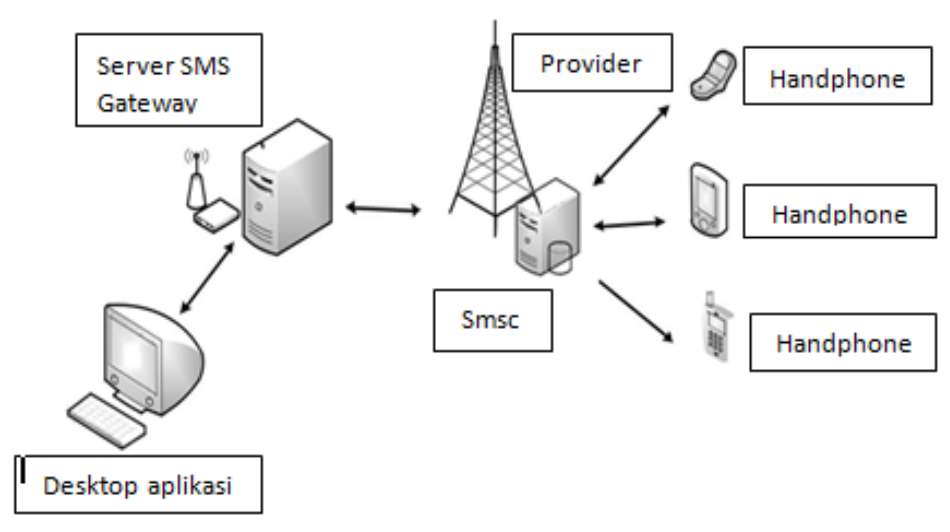

Gambar 3. Model Skema Arsitektur Sms Gateway 


\section{Penggunaan Sms Gateway}

Penggunaan SMS Gateway sudah diterapkan dalam berbagai bidang .antara lain digunakan untuk studi kasus pengajuan proposal skripsi tersebut diterima atau tidak masih dilakukan secara manual, hal ini menjadi keluhan bagi mahasiswa serta tim komisi di Program Studi Teknik Lingkungan Universitas Pembangunan Nasional 'Veteran' Yogyakarta sehingga proposal dengan sistem yang lama masih menggunakan cara yang manual menyebabkan kurang efisien dan kurang memudahkan alur informasi kepada mahasiswa seperti pengajuan hingga mendapat jadwal ujian tugas akhir dan hal-hal yang berhubungan dengan tugas akhir, maka mahasiswa yang mengajukan proposal di awal bisa dengan cepat informasi dari pihak program studi secara otomatis mengirimkan SMS kepada mahasiswa dimana dalam penerapannya menggunakan SMS Gateway kalkun yang sudah ada pengelolaan SMS maka penggunaan tools memanfaatkan SMS Kalkun untuk SMS selanjutnya akan menyimpan dan pengiriman SMS oleh operator yang mengakses aplikasi ini (Roby Medika, 2016). Selanjutnya penggunaan SMS Gateway juga bisa dilakukan untuk para usahawan tertutama dalam studi kasus usaha penyewaan lapangan futsal Aplikasi yang menggunakan SMS Gateway berjalan untuk melayani pemesanan lapangan futsal, dimana aplikasi ini dibangun untuk memperkecil biaya pemesanan yang dilakukan oleh pelanggan dengan SMS dapat mempermudah mendapatkan informasi jadwan dan harga sewa lapangan yang kosong dilakukan oleh pengelola lapangan futsal akan mengirimkan SMS secara otomatis dan pelanggan sesuai format pemesanan sesuai dengan ketentuand dengan memanfaatkan tools gammu untuk mengelola SMS. (Panji Muharif, 2013), Arsitektur dapat di lihat pada Gambar 4.

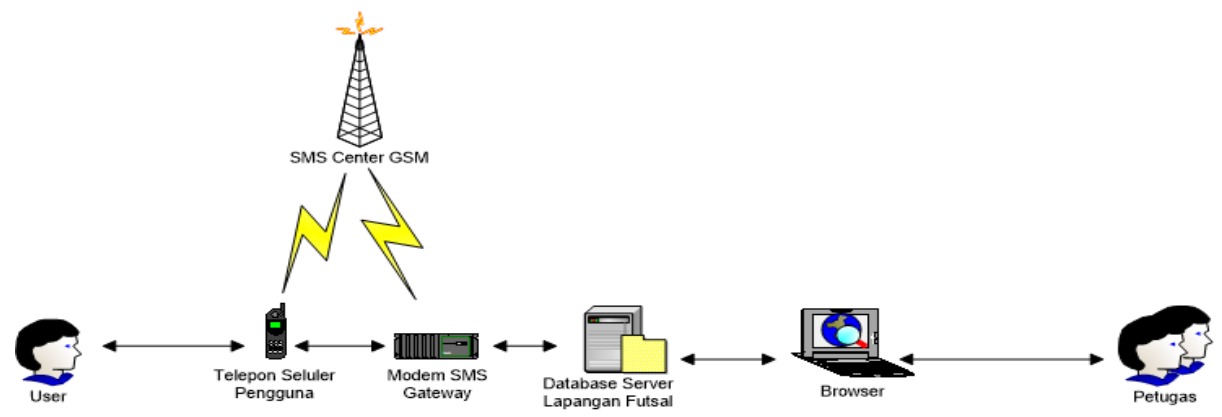

Gambar 4. Arsitektur sistem penyewaan lapangan menggunakan SMS Gateway

Kemudian penelitian yang dilakukan oleh Kharismawan Pudyastowo (2014) yaitu membahas studi kasus mengenai donor darah menggunakan SMS Gateway. Sistem yang masih manual khususnya di Unit Donor Darah dalam menginformasikan persediaan darah dikarenakan banyaknya data yang harus diolah dibutuhkan ketelitian dan publikasi kepada publik dengan memanfaatkan internet dan SMS Gateway dengan jaringan Global System for Mobile Communication (GSM), maka masyarakat dan intansi dapat melihat informasi tentang stok darah melalui website dan menggunakan tools gammu untuk SMS (Kharismawan P. 2014) Arsitektur dapat di lihat pada Gambar 5.

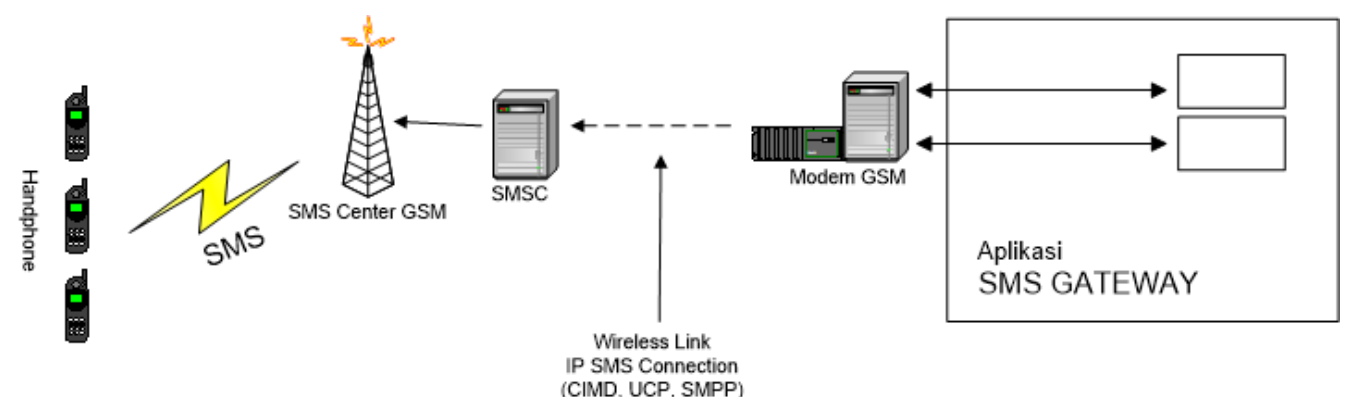

Gambar 5. Arsitektur sistem kehilangan dan penemuan kendaraan dengan fasilitas SMS

Terakhir membahas studi kasus mengenai kehilangan dan penemuan kendaraan bermotor di polres ngawi dikarenakan belum adanya pencatatan yang memuat data-data kendaraan razia 
menggunakan sistem komputer dan pengungkapan secara cepat mengakibatkan pengungkapan kasus berjalan lama. Maka dengan aplikasi ini diharapkan penanggulangan pencurian kendaraan bermotor dengan fasilitas SMS Gateway memanfaatkan tools pada gammu dibangun agar dapat dengan mudah diakses oleh user umum dan pihak kepolisian ngawi sehingga mempercepat dalan penyampaian informasi. Arsitektur dapat di lihat pada Gambar 6.

\section{HASIL DAN PEMBAHASAN}

Setelah penulis melakukan pengumpulan data, melalui oberservasi lapangan dan wawancara, maka data untuk diolah.

\subsection{Perancangan Sistem}

\section{DFD}

Untuk perancangan DFD Level 0 dapat dilihat pada Gambar 7 dan untuk perancangan DFD Level 1 dapat dilihat pada Gambar 8.

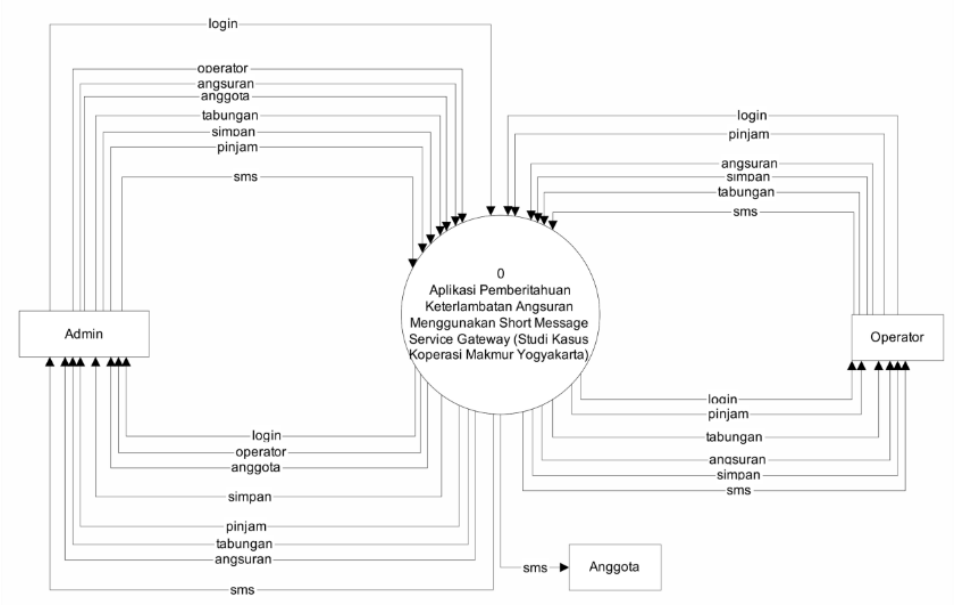

Gambar 7. Data Flow Diagram 0

\section{ERD}

Perancangan ERD dapat dilihat pada Gambar 9. 


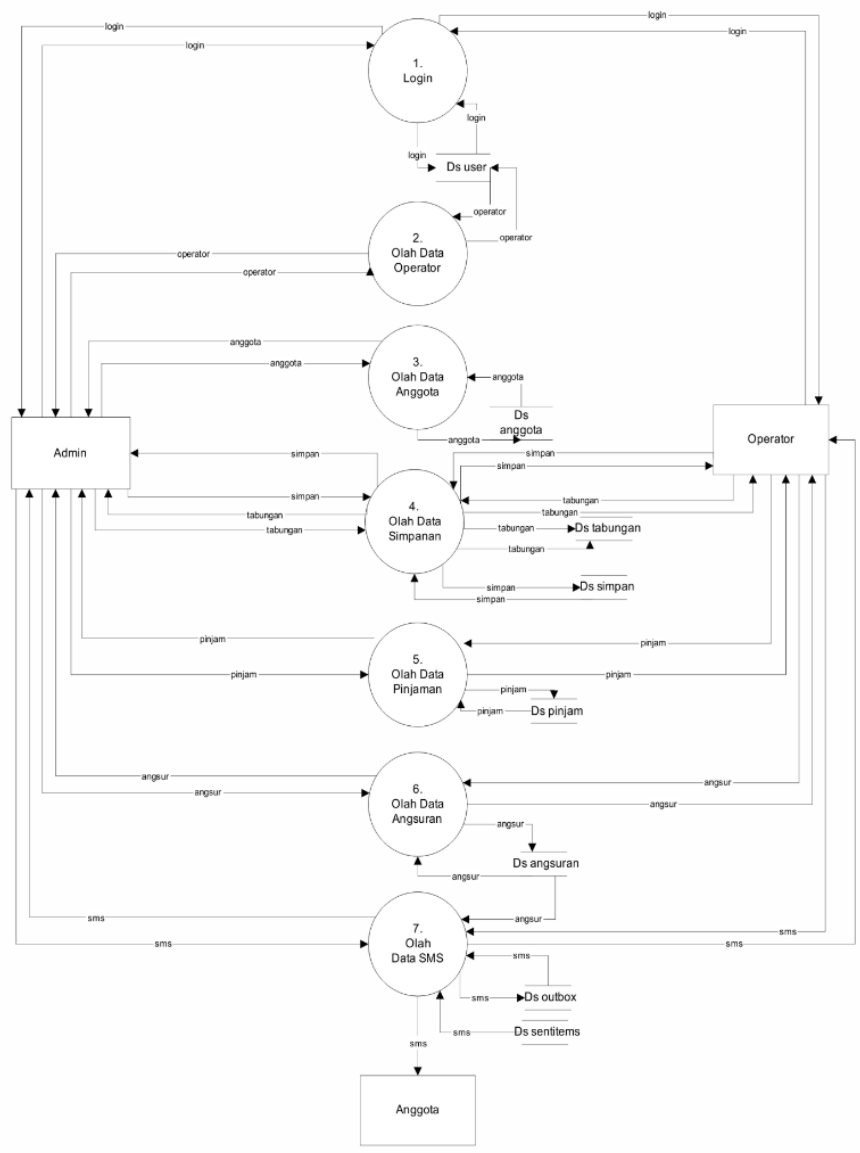

Gambar 8. Data Flow Diagram 1

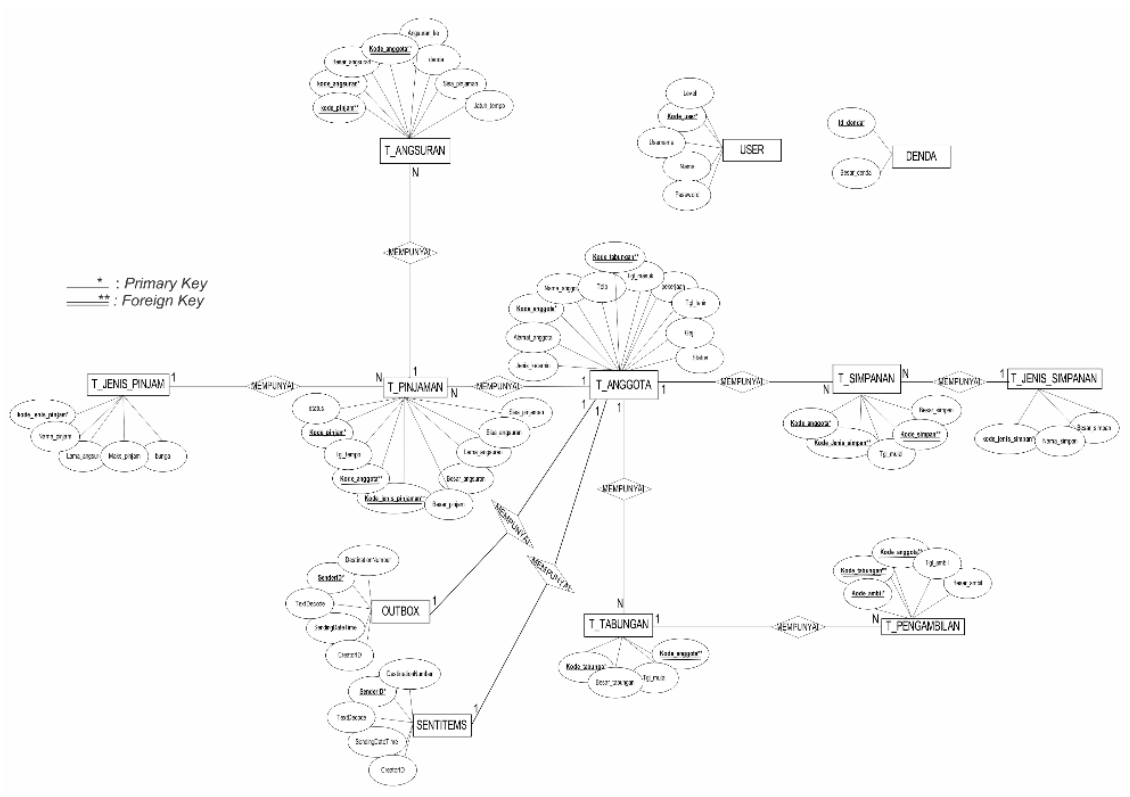

Gambar 9. Entity Relation Diagram 


\section{Flowchart}

Adapun Flowchart perhitungan SMS dapat dilihat pada Gambar 10.

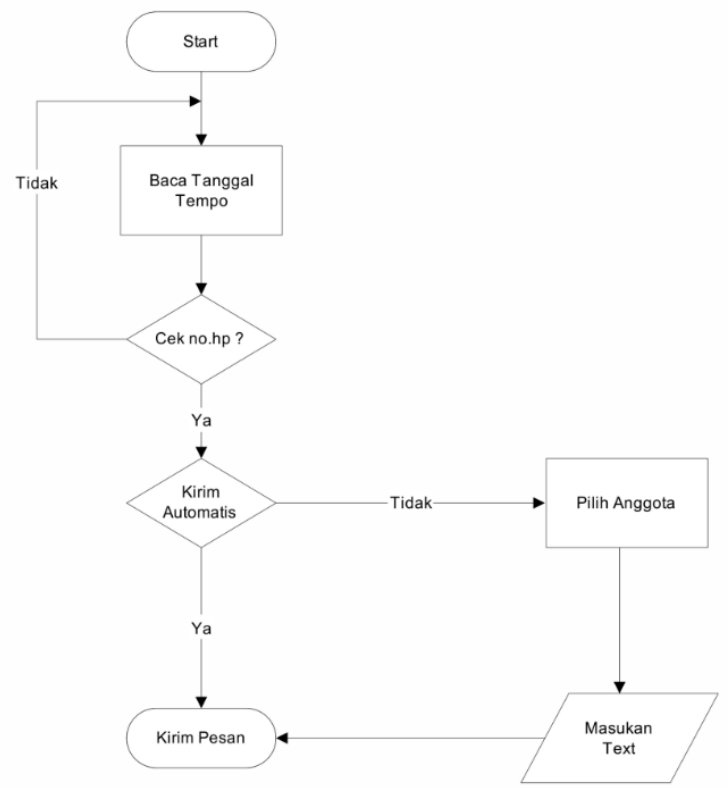

Gambar 10. Flowchart SMS

Pada flowchart diatas, dijelaskan bagaimana sistem ini dibuat dengan memanfaatkan pengiriman SMS dimulai dengan membaca tanggal jatuh tempo, selanjutnya akan tampil data anggota yang terlambat mendekati dan melewati jatuh tempo. Kemudian pengiriman SMS secara otomatis setelah mendekati dan melewati jatuh tempo bisa juga dilakukan secara manual dengan membaca No.Hp kemudian dikirim ke anggota koperasi memanfaatkan gammu.

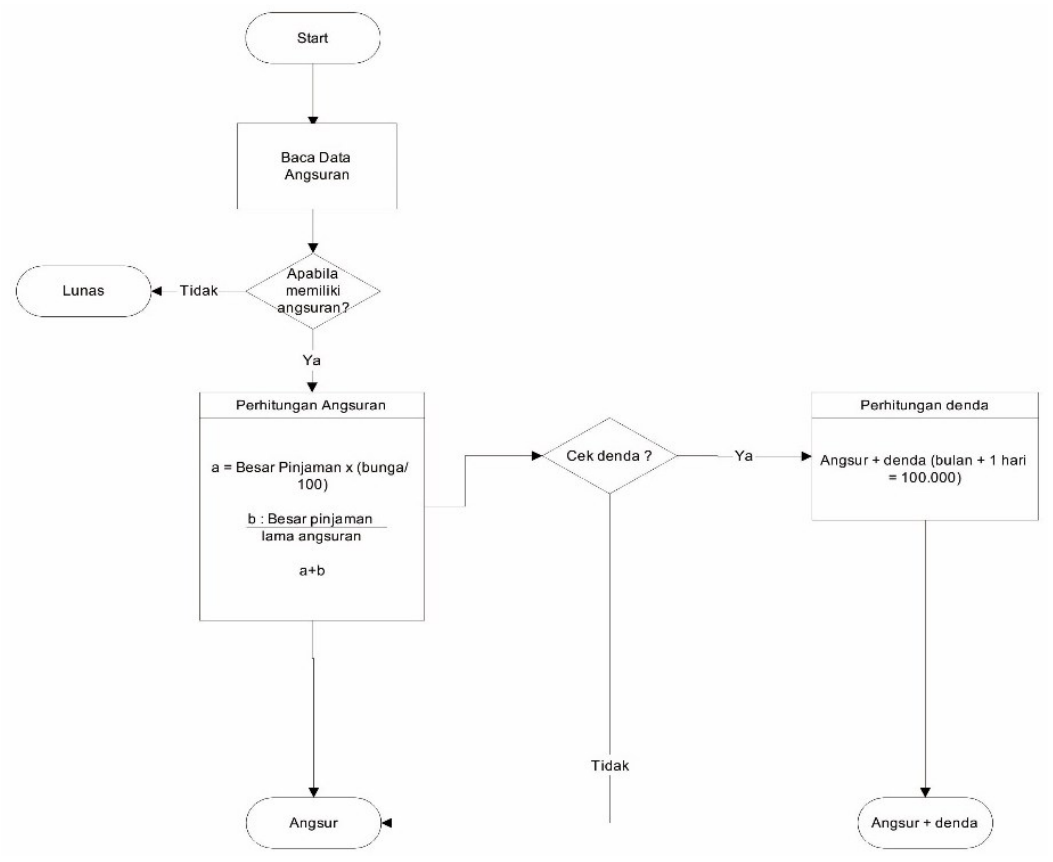

Gambar 11. Flowchart penentuan angsuran

Sedangkan untuk menentukan nominal angka yang akan masukan kedalam teks otomatis Dalam menjalan transaksi angsuran dalam aplikasi ini ada perhitungan dibuat untuk penentuan nilai 
anggsuran $a=$ besar pinjaman dikali bunga,$b=$ besar pinjaman dibagi lama angsuran maka $a+b$ akan terjumlah tiap bulan yang harus dibayarkan tapi jika memiliki denda akan ditambahkan dengan nominal $\mathrm{Rp} 100.000$,- perbulan yang sesuai dengan aturan dari koperasi jika tidak ada angsuran dan denda maka dianggap lunas. Sedangkan untuk penentuan bunga menggunakan metode bunga Flat dengan pokok dalam angsuran bulan akan tetap sama. Dapat dilihat digambar 11 diatas.

\subsection{Pengujian Sistem}

Pengujian sistem merupakan tahap akhir dari perancangan sistem yang dibuat. Tahap pengujian yang dilakukan dengan alpha test dan beta test. Menurut Pressman (2010), pengujian ini bersifat Black Box testing adalah pengujian yang berfokus pada fungsionalitas perangkat lunak. Dengan koresponden 13 orang

\section{Pengujian Alpha}

Hasil uji validasi untuk alpha test ini $65 \%$ responden memberikan jawaban Baik maka dapat disimpulkan bahwa fungsi aplikasi yang telah dibangun telah memenuhi kebutuhan dari pengguna akhir dan dapat diterapkan pada lokasi yang sesungguhnya.

\section{Pengujian Beta}

Hasil uji validasi untuk beta test ini $67.5 \%$ responden memberikan jawaban Baik dengan ada aplikasi ini maka dapat disimpulkan bahwa aplikasi ini cukup efisien dalam menghemat waktu saat proses penyelesaian permasalahan pemberitahuan dan pengelolaan data koperasi dan dibangun dengan memenuhi kebutuhan dari koperasi pada akhirnya sehingga dapat diterapkan pada lokasi yang sesungguhnya.

\section{Hasil Pengujian}

Beberapa proses pengujian alpha dan beta yang dilakukan meghasilkan beberapa hasil. Tentang keefisien waktu dalam pengiriman dan pengelolaan sms melalui gammu diolah melewati media web. SMS dapat diterima dengan baik. Dan Pengiriman SMS cukup begitu baik tersampaikan kepada anggota dan pengelolaan data cukup membantu koperasi khususnya bagi anggota yang menunggak sistem pemberitahuan mendekati dan melewati jatuh tempo sudah cukup membuat waktu lebih efisien karena saat mendekati seminggu sebelum jatuh tempo dan melewati jatuh tempo pertanggal kalender satu bulan setelah peminjaman sistem akan langsung memberi SMS kepada anggota yang bersangkutan. Pengujian yang ini dilakukan dengan lebih dari 10 koresponden. Sedangkan kekurangannya pengujian sistem, diketahui bahwa sistem yang telah dibangun memiliki keterbatasan yaitu, saat melakukan SMS masih terasa harus menunggu karena setiap tempat memiliki sinyal yang berbeda dan provider yang memiliki kelemahan berbeda-beda maka tiap secara realtime walaupun akhirnya dapat terkirim . Selain itu proses dalam aplikasi akan berhenti ketika terjadi pemadaman listrik.

\section{a. Aplikasi Program}

Pada bagian ini dibahas mengenai SMS Pemberitahuan yang dapat dilakukan oleh admin dan operator dengan cara manual maupun otomatis.

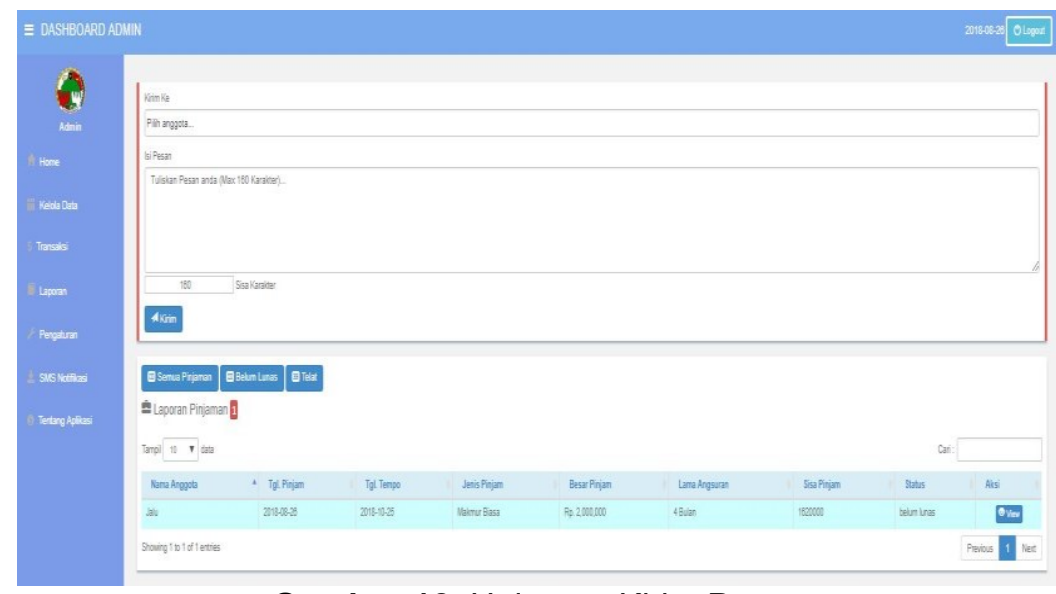

Gambar 12. Halaman Kirim Pesan 
Halaman ini merupakan halaman untuk mengirim sms pemberitahuan kepada setiap anggota sudah terlambat membayar angsuran melewati jatuh tempo dengan sort by nilai sisa angsuran tertinggi secara manual dan secara otomatis mengirim sms apabila sudah mendekati dan melewati tanggal jatuh tempo. Dapat dilihat pada Gambar 12 diatas.

\begin{tabular}{|c|c|c|c|c|c|}
\hline \multicolumn{4}{|c|}{ A Kotak Keluar 1} & \multicolumn{2}{|c|}{ AKirim Pesan } \\
\hline No & Nama Tujuan & № Hp & Isi Pesan & Waktu Kirim & Aksi \\
\hline 1 & $\begin{array}{l}\text { Ida Bagus Made } \\
\text { Putra }\end{array}$ & 081382649052 & $\begin{array}{l}\text { Angsuran Anda Sebesar Rp } 270000 \text { Sudah Mendekati Tanggal Jatuh Tempo, Harap Segera Membayar } \\
\text { Angsuran }\end{array}$ & $\begin{array}{l}2018-10-23 \\
21: 33: 00\end{array}$ & ẼHapus \\
\hline \multicolumn{4}{|c|}{ A Pesan Terkirim 2} & \multicolumn{2}{|c|}{ AKirim Pesan } \\
\hline No & Nama Tujuan & No Hp & Isi Pesan & Waktu Terkirim & Aksi \\
\hline 1 & $\begin{array}{l}\text { Ida Bagus Made } \\
\text { Putra }\end{array}$ & 081382649052 & $\begin{array}{l}\text { Angsuran Anda Sebesar Rp } 270000 \text { Sudah Melewati Tanggal Jatuh Tempo, Harap Segera Membayar } \\
\text { Angsuran }\end{array}$ & $\begin{array}{l}2018-10-23 \\
21: 36: 20\end{array}$ & ËHapus \\
\hline 2 & $\begin{array}{l}\text { Ida Bagus Made } \\
\text { Putra }\end{array}$ & 081382649052 & $\begin{array}{l}\text { Angsuran Anda Sebesar Rp } 270000 \text { Sudah Mendekati Tanggal Jatuh Tempo, Harap Segera Membayar } \\
\text { Angsuran }\end{array}$ & $\begin{array}{l}2018-10-23 \\
21: 33: 47\end{array}$ & Ẽ Hapus \\
\hline
\end{tabular}

Gambar 13. Mendekati jatuh tempo

Proses sms secara otomatis sebelum dan mendekati jatuh tempo dengan sms kode 1 setelah melewati jatuh tempo dan sms kode 2 mendekati jatuh tempo kemudian akan tersimpan dalam outbox database gammu. Dapat dilihat pada Gambar 13 dan 14.

\begin{tabular}{|c|c|c|c|c|c|}
\hline \multicolumn{5}{|c|}{ E Kotak Keluar 1} & Kirim Pesan \\
\hline No & Nama Tujuan & № Hp & Isi Pesan & Waktu Kirim & Aksi \\
\hline 1 & $\begin{array}{l}\text { Ida Bagus Made } \\
\text { Putra }\end{array}$ & 081382649052 & $\begin{array}{l}\text { Angsuran Anda Sebesar Rp } 270000 \text { Sudah Melewati Tanggal Jatuh Tempo, Harap Segera Membayar } \\
\text { Angsuran }\end{array}$ & $\begin{array}{l}2018-10-23 \\
21: 35: 34\end{array}$ & Ể Hapus \\
\hline \multicolumn{4}{|c|}{ Pesan Terkirim 2} & \multicolumn{2}{|c|}{ A Kirim Pesan } \\
\hline No & Nama Tujuan & No Hp & Isi Pesan & Waktu Terkirim & Aksi \\
\hline 1 & $\begin{array}{l}\text { Ida Bagus Made } \\
\text { Putra }\end{array}$ & 081382649052 & $\begin{array}{l}\text { Angsuran Anda Sebesar Rp } 270000 \text { Sudah Melewati Tanggal Jatuh Tempo, Harap Segera Membayar } \\
\text { Angsuran }\end{array}$ & $\begin{array}{l}2018-10-23 \\
21: 36: 20\end{array}$ & Êpus \\
\hline 2 & $\begin{array}{l}\text { Ida Bagus Made } \\
\text { Putra }\end{array}$ & 081382649052 & $\begin{array}{l}\text { Angsuran Anda Sebesar Rp } 270000 \text { Sudah Mendekati Tanggal Jatuh Tempo, Harap Segera Membayar } \\
\text { Angusuran }\end{array}$ & $\begin{array}{l}2018-10-23 \\
21: 33: 47\end{array}$ & Ền Hapus \\
\hline
\end{tabular}

Gambar 14. Melewati jatuh tempo

Berikut hasil dari sms pemberitahuan angsuran secara otomatis pada saat mendekati dan melewati jatuh tempo. Dapat dilihat pada Gambar 15.

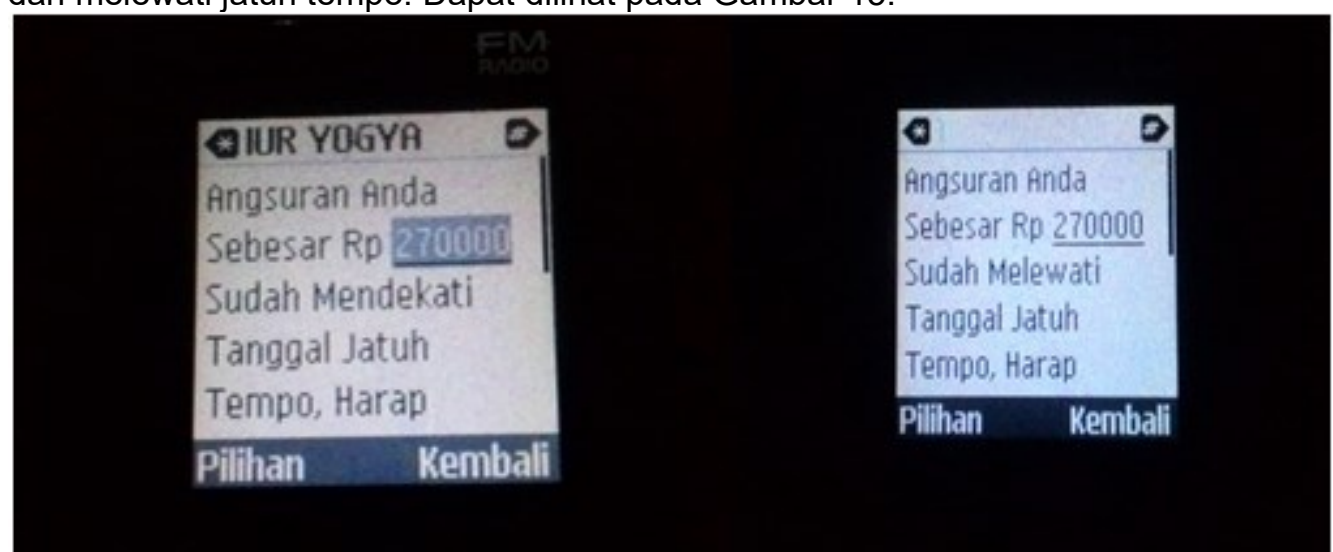

Gambar 15. Hasil sms otomatis 


\section{KESIMPULAN}

Berdasarkan dari hasil yang telah tercapai, didapatkan sebuah Aplikasi Pemberitahuan Keterlambatan Pembayaran Angsuran Menggunakan Short Message Service Gateway (Studi Kasus Koperasi Simpan Pinjam Makmur Yogyakarta). Beberapa kesimpulan yang dapat diambil adapun manfaat aplikasi ini, antara lain:

- Dengan adanya teknologi gammu sebagai penyedia dan pengelola SMS sehingga teknologi ini dapat melakukan pengeolaan dan pengiriman SMS kepada setiap anggota yang melewati dan seminggu mendekati jatuh tempo sebagai sarana pemberitahuan informasi.

- Memudahan pengelolaan rekam data koperasi dengan output laporan dan pemberitahuan informasi pembayaran angsuran.

- Dapat membantu anggota mendapatkan informasi pembayaran angsuran sehingga tidak terjadi kemungkinan penunggakan.

- Dengan adanya menu SMS Notifikasi memudahkan koperasi dalam memberikan informasi pembayaran angsuran atau informasi lain yang diharapkan dapat membuat waktu lebih efisien saat sehingga dapat menjawab permasalahan mengenai keefisienan dan penunggakan angsuran.

\section{DAFTAR PUSTAKA}

Alfian. Ghurfan Yusuf. 2013. Perancangan dan Implementasi Sistem Informasi Koperasi Multiguna Berbasis Web (Studi Kasus Koperasi Multiguna Kecamatan Panekan). Other thesis, Program Studi Teknik Informatika Fakulta Sains dan Teknologi Universitas Islam Negeri Sunan Kalijaga Yogyakarta.

Cahya Kurnia. Anjar . 2016. Sistem Informasi Simpan Pinjam Pada Koperasi Makmur Mandiri Bandung. Other thesis. Program Studi Sistem Informasi, Universitas Komputer Indonesia Bandung.

Ferry, Gunawan. 2003. "Membuat Aplikasi SMS Gateway dan Client dengan Java dan PHP”, PT Elex Media Komputindo, Jakarta

J. . P. Jumri . 2012, "Perancangan Sistem Monitoring Konsultasi Bimbingan Akademik

Mahasiswa dengan Notifikasi Realtime Berbasis SMS Gateway," Informatika, pp. 34-55.

Jogiyanto. 2005. Analisis \& Desain Sistem Informasi : pendekatan terstruktur teori dan praktek aplikasi bisnis. Andi, Yogyakarta.

Kadir . Abdul. 2003. Pengenalan Sistem Informasi. CV Andi Offset. Yogyakarta.

Muharif. Panji . 2013. Aplikasi Berbasis Web Pengelolaan Sewa Lapangan Futsal Dan Layanan Informasi Serta Pemesanan Menggunakan SMS Gateway. Other thesis. Fakultas Teknik Industri, Universitas Pembangunan "Veteran" Nasional Yogyakarta.

Nindyo Pramono, 1986, Beberapa Aspek Koperasi pada Umumnya dan Koperasi Indonesia di dalam Perkembangan, TPK Gunung Mulia. Yogyakarta.

Pudyastowo. Kharismawan. 2014. Aplikasi Stock Darah Berbasis Web dan SMS Gateway Pada Unit Donor Darah PMI Kabupaten Klaten. Other thesis. Fakultas Teknik Industri, Universitas Pembangunan "Veteran" Nasional Yogyakarta.

Pressman, R.S. (2010), Software Engineering : a practitioner's approach,McGraw-Hill, New York, 68

Rahardja, R.T. Sutantya. 2000. Hukum Koperasi Indonesia. PT Raja Grafindo Persada. Jakarta. 
Riadi, M. (2012, December 04) . Teori SMS (Short Message Service). Retrieved March 06, 2013, fromKajian Pustaka:http://www.kajianpustaka.com/2012/12/teori-sms-shortmessage service.html.

Rakmansyah. Mulya. 2011. "Analisa dan Perancangan Sistem Informasi Simpan Pinjam Berbasis Web (Studi Kasus : Koperasi Pegawai Negeri IGTKI PGRI Pekanbaru ). Other thesis, Universitas Islam Negeri Sultan Syarif Kasim Riau Pekanbaru.

Sunardi. 2009. Aplikasi SMS Gateway -Vol 14, No. 1. Sunardi. Jakarta.

Sibero. Alexander F.K., 2011, Kitab Suci Web Programing, MediaKom ,Yogyakarta.

Sutanta, Edhy. 1995. Sistem Informasi Manajemen. Graha IImu. Yogyakarta.

Setyo Budi. Yoni . 2013. Aplikasi Pelayanan Pencurian Kendaraan Bermotor Dengan Menggunakan Fasilitas SMS Gateway. Other thesis. Fakultas Teknik Industri, Universitas Pembangunan "Veteran" Nasional Yogyakarta.

Kompasiana. (2012, 09 20). Tahun 2012 angka penculikan anak meningkat. Retrieved 13 11,2018,fromhttps://www.kompasiana.com/arozisokhi_azjava/5517b539a333115107 b65fc3/dampak-perkembangan-teknologi-informasi 